\title{
Sentinel event in oral health: experience with children with up to six years of age, users of the Unified Health System
}

\author{
Evento sentinela em saúde bucal: experiência com crianças até seis anos de idade usuárias do Sistema \\ Único De Saúde
}

Nora Nei Reis PEREIRA'

(iD) ORCID ID 0000-0002-8113-059X

Saul Martins PAIVA²

(iD) ORCID iD 0000-0002-3968-1638

Eliana Maria de Oliveira SÁ3

(iD) ORCID iD 0000-0001-5839-7934

Rafaela da Silveira PINTO 4

(iD) ORCID iD 0000-0002-6169-7708

Simone Dutra LUCAS 5

(iD) ORCID ID 0000-0001-7875-4492

\section{ABSTRACT}

\section{Objective}

The aim of this study was to find out the children's profile identified as Sentinel Event in oral health by the Municipal Health Department of the city of Belo Horizonte, State of Minas Gerais, Brazil.

\section{Methods}

A quantitative, analytical, exploratory and documentary analysis study was developed in the city of Belo Horizonte, State of Minas Gerais, Brazil, involving 545 children, age ranging from zero to six years old. Sentinel event data were collected through an electronic form created in the Unified Health System and filled out by the municipal oral health teams. Information systems of the city council were consulted. The variables studied were as follows: Health Vulnerability Index, race/color, age, sex, to be beneficiary of the Bolsa Familia Program (a social program sponsored by the government), to be monitored by the Strategy of the Family Health Program, to reside in the Belo Horizonte Citizenship Program area, nature of the school and region of residence. Statistical analysis was performed in the SPSS software, $20^{\text {th }}$ version.

\section{Results}

The results showed that the majority of children live in areas of medium and high social risk, they are five to six years old, male, dark-skinned, do not benefit from the Bolsa Familia program, are not under the Strategy of the Family Health Program, do not reside in the territory of the Belo Horizonte Citizenship Program, and study in institutions of the municipal education network. The sentinel event is present in the nine regions of Belo Horizonte, with a higher prevalence in the regions of Venda Nova, Northeast, West, East and Barreiro.

\section{Conclusion}

The study demonstrates the crucial importance of comprehensive social policies in order to influence oral health.

Indexing terms: Child. Dental caries. Oral health. Primary health care. Public health. Sentinel event surveillance.

\section{RESUMO}

\section{Objetivo}

Conhecer o perfil das crianças identificadas como evento sentinela em saúde bucal pela Secretaria Municipal de Saúde de Belo Horizonte.

Métodos

Um estudo quantitativo, analítico, exploratório e de análise documental, foi desenvolvido em Belo Horizonte, Brasil, envolvendo 545 crianças de zero a sels anos de idade. Os dados dos eventos sentinela foram coletados por meio de um formulário eletrônico criado no Formulário do Sistema Unico de Saúde e preenchido pelas equipes de saúde bucal municipais. Também foram consultados sistemas de informacão da Prefeitura Municipal de Belo Horizonte. As variáveis estudadas foram: Índice de Vulnerabilidade à Saúde, raça/cor, idade, sexo, ser beneficiário do Programa Bolsa Família, ser acompanhado pela Estratégia da Saúde da Família, residir na área do Belo Horizonte Cidadania, natureza da instituição escolar e regional de residência. A análise estatística foi realizada no programa SPSS versão 20.0.

\section{Resultados}

A maior parte das crianças reside em áreas de média e elevada vulnerabilidade à saúde, são pardas, têm de cinco a seis anos de idade, são do sexo masculino, não beneficiárias do Programa Bolsa família, não são acompanhadas pela Estratégia Saúde da Família, não residem em território do Programa BH cidadania e estudam em instituições próprias da rede municipal de ensino. O evento sentinela está presente em toda a cidade de Belo Horizonte, com maiores prevalências nas regionais Venda Nova, Nordeste, Oeste, Leste e Barreiro.

\section{Conclusão}

O estudo demonstra como a adoção de políticas sociais abrangentes pode influenciar a situação de saúde bucal.

Termos de indexação: Criança. Cárie dentária. Saúde bucal. Atenção primária à saúde. Saúde pública. Vigilância de evento sentinela.

${ }^{1}$ Prefeitura de Belo Horizonte, Secretaria Municipal de Saúde/Coordenação de Saúde Bucal. Av. Afonso Pena, 2336, 4º andar, Funcionários, 30130-007, Belo Horizonte, MG, Brasil. Correspondência para / Correspondence to: NNR PEREIRA. E-mail: <noranrpereira@gmail.com>.

${ }^{2}$ Universidade Federal de Minas Gerais, Faculdade de Odontologia, Departamento de Odontopediatria e Ortodontia. Belo Horizonte, MG, Brasil.

${ }^{3}$ Prefeitura de Belo Horizonte, Secretaria Municipal de Saúde/Gerência de Assistência à Saúde. Belo Horizonte, MG, Brasil.

${ }^{4}$ Secretaria de Estado de Saúde de Minas Gerais/Coordenação de Saúde Bucal. Belo Horizonte, MG, Brasil.

${ }^{5}$ Universidade Federal de Minas Gerais, Faculdade de Odontologia, Departamento de Odontologia Social e Preventiva. Belo Horizonte, MG, Brasil.

$\checkmark v \boldsymbol{V}$

Como citar este artigo / How to cite this article

Lacerda EPM, Martorelli SBF, Martorelli FO. Dentigerous cyst in the maxillary posterior region associated with an impacted deciduous molar. RGO, Rev Gaúch Odontol. 2018;66(2):00-00. http://dx.doi.org/10.1590/1981-8637201800020000153279 


\section{INTRODUCTION}

In 1976, the sentinel event was conceptualized as occurring situations such as unnecessary diseases, disabilities and needless premature deaths, which could be avoided if health services functioned as they should [1]. As soon as a sentinel event is found, it is of utmost importance that a careful investigation is carried out in order to discover failures or determinants so that corrective measures can be implemented to ensure the correct functioning of the health system [1].

The sentinel event is a negative health indicator, however its use to assess the quality of health care is simpler and cheaper compared to the global approach observation of entire populations for the occurrence of health-damaging factors [2]. Research in several areas such as medicine, nursing, epidemiology, health services management were developed using the concept of sentinel event proposed in 1976 [1-9]. The oral health sentinel event, in Belo Horizonte, refers to children up to six years of age, presenting more than eight teeth with carious cavity lesions [10]. However, in a literature review where the terms sentinel event and dental caries were used (in Portuguese and English), in the Pubmed, Scielo, Lilacs and BBO databases, no scientific article was found. This study aims to find out the profile of children identified as a sentinel event in oral health by the Municipal Health Department of the city of Belo Horizonte, State of Minas Gerais, Brazil.

\section{METHODS}

This is a quantitative, analytical, exploratory and documentary analysis study developed in the Belo Horizonte Unified Health System network (SUSBH). Census data were used to identify children aged 0-6 years old, enrolled in public schools in Belo Horizonte and classified as a sentinel event according to the definition of the Municipal Health Department. The study sample was composed of 545 children from zero to six years old who were identified as sentinel event in oral health, from January to October 2016 and the data base used to search for information are all from the City of Belo Horizonte. In the Municipal Health Secretariat (MHS), the Health Information System Network (HISN) was used; the Municipal Education Department (MED) made use of the School Management System (SMS) and the Municipal Social Policy Secretariat (MSPS) used the Information and Social Policy Management (ISPM).

Data on sentinel event children were collected through an electronic form created specifically for this purpose in the Unified Health System Form (UHSF) filled out by the oral health teams (OHT) of the 150 Health Centers responsible for monitoring the schools under the coverage area. Other documents consulted were made available by the Oral Health Coordination of the Municipal Health Secretariat.

FormSUS- is a service provided by the Ministry of Health through the Department of Information Technology of the National Health System (DATASUS). It is used to create forms on the web, designed to provide agility, structuring and quality to the process of collecting and disseminating data over the Internet. It enables realtime monitoring of data collection and its results [11]. Initially the report extracted from FormSus contained 722 children. Exclusion criteria consisted of residents in other municipalities, those collected in years prior to 2016, those born before January 1, 2009, and duplicates. After the exclusions, 545 children were eligible to participate in the study. The variables studied were: Health Vulnerability Index $(\mathrm{HVI})$, race / color of the skin, age, sex, to be a beneficiary of the Bolsa Família Program, to be assisted by the Family Health Strategy, residing in the BH Citizenship area, the kind of school the child is enrolled and the region of the child's residence. Among the mentioned variables, some of them are especially used in Belo Horizonte such as $\mathrm{HVI}, \mathrm{BH}$ citizenship, the kind of the school institution and administrative regions. Since 1998, the municipality of Belo Horizonte has been using $\mathrm{HVI}$ to capture local realities in order to guide public health policies and prioritize resource allocation. The HVI indicator uses different variables, from the Demographic Census of the Brazilian Institute of Geography and Statistics (IBGE), among them: sanitation, housing, schooling, income, among others [12]. The 2012 HVI was used for this study.

In 2002, Belo Horizonte implemented the social program $\mathrm{BH}$ Citezenship. It was structured based on decentralization, intersectoriality, territoriality and citizen participation including the nine health regions of the city. The focus of the program concerns areas of great social vulnerability, identified through various social indicators, generating the Map of Priority Areas for Social Inclusion.

The $\mathrm{BH}$ Citizenship integrates the actions of the Secretariats of Social Assistance, Food and Nutrition Security, Citizenship Rights, Sports and Leisure, Education, Health, the Municipal Foundation of Culture and the Information Technology Company of the Municipality of Belo Horizonte (Prodabel). It focuses on the family and not on the individual, himself. Nowadays Belo Horizonte has 33 centers, benefiting around 165 thousand families. These 
programmes support the families assisted by providing activities such as telecenters, cultural workshops, Segundo Tempo, City Gyms, among others. One of the axes of the program is the investment in health prevention actions, seeking to promote effective changes in habits and living conditions [13].

The nature of the institution refers to the administrative dependency of the school, whether it is state, municipal, or a partner with the City of Belo Horizonte; and to the location and way of the sentinel child event. In 1983, Belo Horizonte was divided into nine administrative regions and in each one there is a corresponding sanitary district. It works as a decentralized management of the whole organization of the municipality. In 2011 there was, for the first time, territory rearrangement in order to balance the number of inhabitants between the regions.
Each district is subdivided into areas of coverage and the $\mathrm{HVI}$ of this population was mapped.

The descriptive statistical analyzes of the variables included in the study were performed in the SPSS program version 20.0. The present study complied with all the ethical principles contained in the Declaration of Helsinki (2000) and was approved by the Ethics and Research Committee (COEP/ERC) of the Federal University of Minas Gerais under registration CAAE - 61341716.2.0000.5149.

\section{RESULTS}

This study included a total of 545 children up to six years of age who were SUSBH users, classified as sentinel event. All variables with their results can be observed in Table 1

Table 1. Sentinel event children distribution.

\begin{tabular}{|c|c|c|c|}
\hline Variable & & $\mathbf{n}$ & $\%$ \\
\hline & Low & 46 & 8.4 \\
\hline \multirow[t]{4}{*}{ HVI } & Medium & 222 & 40.7 \\
\hline & High & 196 & 36.0 \\
\hline & Very high & 81 & 14.9 \\
\hline & Yellow & 3 & 0.6 \\
\hline \multirow[t]{6}{*}{ Race/Colour of skin } & White & 109 & 20.0 \\
\hline & Dark-skin & 375 & 68.8 \\
\hline & Black & 57 & 10.5 \\
\hline & Not stated & 1 & 0.2 \\
\hline & Two & 6 & 1.1 \\
\hline & Three & 39 & 7.2 \\
\hline \multirow[t]{4}{*}{ Age } & Four & 95 & 17.4 \\
\hline & Five & 159 & 29.2 \\
\hline & Six & 181 & 33.2 \\
\hline & Seven & 65 & 11.9 \\
\hline \multirow[t]{2}{*}{ Sex } & Female & 243 & $44 ., 6$ \\
\hline & Male & 302 & 55.4 \\
\hline \multirow[t]{2}{*}{ Beneficiary of Bolsa Família } & No & 432 & 79.3 \\
\hline & Yes & 113 & 20.7 \\
\hline \multirow[t]{2}{*}{ Assisted by FHS } & No & 301 & 55.2 \\
\hline & Yes & 244 & 44.8 \\
\hline \multirow[t]{2}{*}{ Beneficiary of $\mathrm{BH}$ Citizenship } & No & 328 & 60.2 \\
\hline & Yes & 217 & 39.8 \\
\hline \multirow[t]{4}{*}{ Capture location of Sentinel event } & State school & 45 & 8.3 \\
\hline & Municipal school & 331 & 60.7 \\
\hline & Partner school & 165 & 30.3 \\
\hline & Sponteneous Demand & 4 & 0.7 \\
\hline \multirow[t]{9}{*}{ Residence region } & Barreiro & 63 & 11.6 \\
\hline & Centro Sul & 41 & 7.5 \\
\hline & Leste & 71 & 13.0 \\
\hline & Nordeste & 82 & 15.0 \\
\hline & Noroeste & 49 & 9.0 \\
\hline & Norte & 50 & 9.2 \\
\hline & Oeste & 73 & 13.4 \\
\hline & Pampulha & 32 & 5.9 \\
\hline & Venda Nova & 84 & 15.4 \\
\hline
\end{tabular}


Regarding $\mathrm{HVI}$, most of the children were of medium and high risk, living in the sanitary districts of Venda Nova, Northeast, West, East and Barreiro as can be observed in Figure 1.

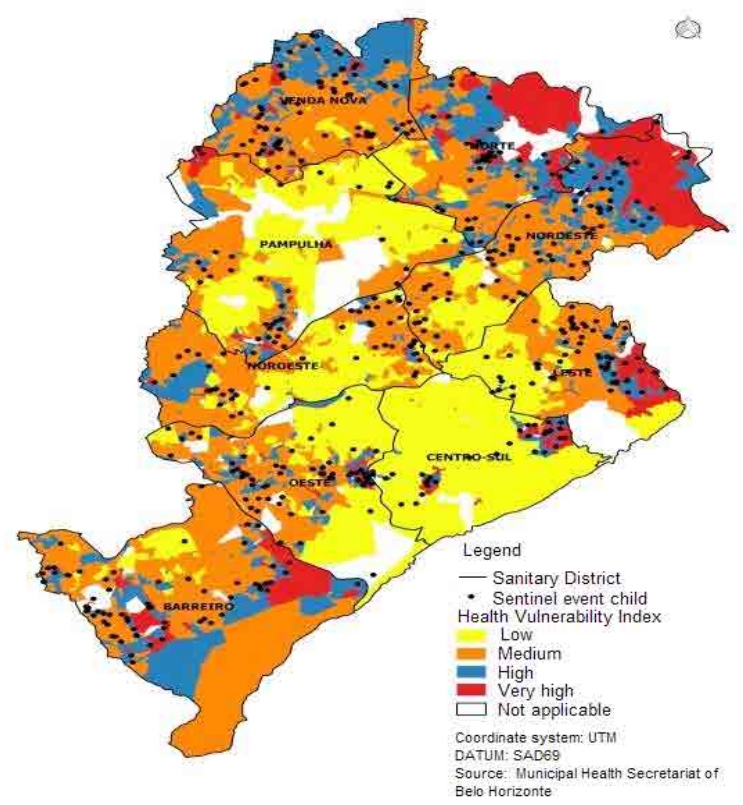

Figure 1. Distribution of children sentinel event in oral health by $\mathrm{HVI}$ and as for race I color of the skin, most of the children were dark-skinned. Note: Municipal Health Secretariat of Belo Horizonte, 2012- Secret FormSUS, 2016.

Regarding age there are more five and six-year old children than other ages, as can be observed in Figure 2 .

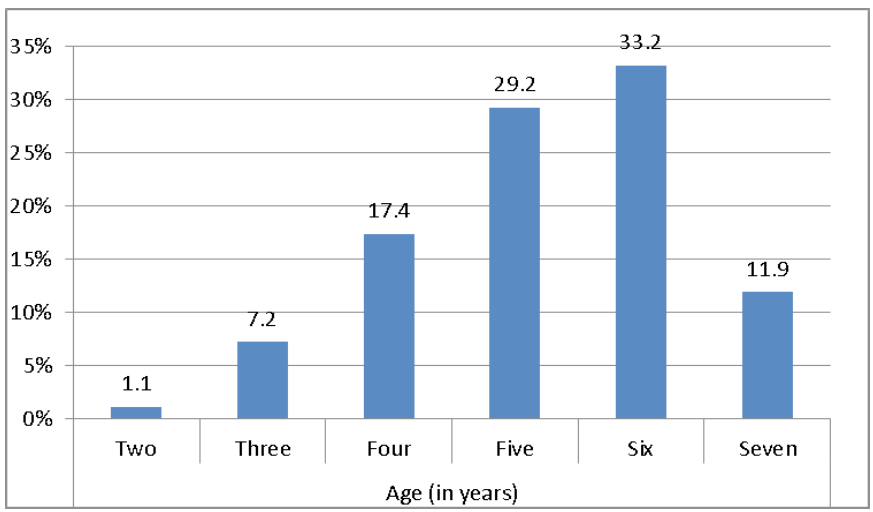

Figure 2. Distribution of children regarding age sentinel event. Note: FormSUS, 2016

The sex difference was very small with a slight male predominance. Regarding social programs, it is observed that most of the children are not beneficiaries of the Bolsa Família Program, are not assisted by the Family Health Team, and are not residents of the BH Citizenship Program area as shown in Figure 3.

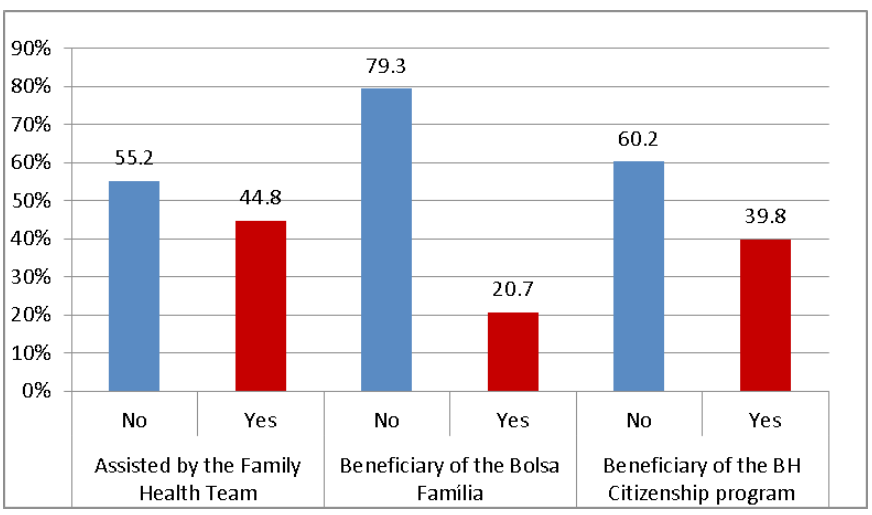

Figure 3. Distribution of sentinel events according to social programs. Note: SMSA/SISREDE; SMED/SGE; Health Centers; FormSUS, 2016

Regarding the kind of the institution, most of the children were captured in the schools of the municipal network. The largest number of children sentinel event was found in the municipal network for early childhood education, followed by the partner institutions of the city. This can be explained by the number of registrations open to the population. The municipal school network is composed of the Municipal Units of Early Childhood Education (MUCEE), Municipal Schools of exclusive Early Childhood Education (MSECE) and Municipal Schools with classes of Early Childhood Education (MECECE). In 2016, 26,359 enrollments were carried out by the Municipal Secretariat in early childhood education. Of this total, $57.3 \%$ were in the Municipal Units of Early Childhood Education/ MUCEE, $5.9 \%$ in the Municipal Schools of exclusive Early Childhood Education/ MSECE, 2.1\% in the / Municipal Schools with classes of Early Childhood Education /MECECE and 34.7\% in the day care centers.

\section{DISCUSSION}

The distribution of children sentinel event in oral health was greater in territories of medium and high health risks, as expected in census sectors of very high health risk. This idea came mainly from the testimony of professionals of the Family Health Team in the cases follow-up. The monitoring reports of the sentinel event showed records that also pointed to this expectation. In these records, there is evidence that sentinel children are (or have been) under some form of violence (psychological, physical, sexual), malnutrition, and neglect. The fact that the greatest number of children are distributed in the group of Middle Risk goes against one of the hypotheses of this work. The predominant race / color of skin in the sentinel event was dark-skin. Among the poorest sections 
of the population, there is a large number of black people. As this information is self-reported, probably due to racial discrimination, mothers refuse to recognize their children as black. Studies show that the skin color of the children, whose parents have the combination with the black color, is declared with clearer results and the combinations with brown tend to produce dark-skin result.

In the Census of 1980, there was an obvious preference to declare children under one year old as being white, even with the mother being of another skin color. In a study developed in 2012 it was found that blacks and dark-skinned are the most vulnerable to health and oral health, as compared to whites $[14,15]$. Blacks have poor access to public policies of income distribution, health care, low schooling and more unemployment.

Regarding age, the predominance of 6 year-old children sentinel event, followed by five-year old children was observed. This is probably due to the cumulative feature of the disease $[16,17]$. Five- and six-year-olds are more exposed to cariogenic factors; this would explain why the largest number of children sentinel event at these two ages. The chance of five- and six-year-old children presenting higher caries-related problems is higher than for children of smaller ages, independently of other variables, as demonstrated by another study about the dental caries experience in preschoolers in Belo Horizonte [18]. In this study, sentinel children who are seven years old are those who had been on the test for more than six years, were not yet seven years old and who by the time of the examination had already reached this age.

The male sex, as a sentinel event in oral health, presented a slight predominance. Several studies have shown little or no relation of sex with caries activity $[19,20]$. However, a study with preschoolers has demonstrated that five year-old boys with a greater experience of caries as well as the teeth lost proportion was higher than in girls [21]. Some authors $[22,23]$ considered being a female, as a caries protection factor.

A contradictory result concerning the initial expectation of this study was the fact that only $20 \%$ of sentinel children are benefited by the Bolsa Família Program. The possible explanation for this result is that the program, when developing activities of health education and health promotion protects the development of dental caries in these children [24]. Since 2006, as provided in the "Basic Health Dental Care Protocol", fluoride toothpaste, toothbrushes and floss are distributed in a hygienic kit format, especially for the population benefited by the program [25]. Access to the benefits of low fluorine concentration and high frequency distribution may be related to the results found in this study.

Another aspect analyzed is that most children sentinel event are not assisted by the Family Health Strategy, which is another policy that provides the child's protection concerning health promotion. It should be noted that many children enrolled in health centers do not receive a home visit by the community health agent. Thus even using some primary care service they are not assisted by the local FHS teams. There may be children sentinel event in these conditions, especially at low risk.

Regarding BH Citizenship, we had only $40 \%$ of the children sentinel event residents in areas where the program operates. When analyzing the social programs, it was observed that there was a benefit of the children who were of the $\mathrm{BH}$ citizenship, who represented the poorest, and of the beneficiary children of the Bolsa Família Program. If on one hand it seems contradictory not to have found many children of very high $\mathrm{VHI}$, on the other, $\mathrm{BH}$ has been developing social programs that have a protective effect on this population.

In relation to state schools, the small number of children sentinel event found is consistent with the small number of children enrolled in state education in Belo Horizonte. The Law of Guidelines and Bases of Education defines that it is the responsibility of the State to guarantee free assistance in kindergarten and preschool for children from zero to six years of age. The EducaCenso 2015 shows that only 495 enrollments in state education were carried out in Minas Gerais [26]. Not being enrolled in any educational institution and not attending preschool are risk factors for caries $[19,27]$. The fact that the capture of the majority of children sentinel event has been in the school physical space reinforces the need and importance of the Health Program in the School for the actions of health promotion and protection of the child. In Belo Horizonte, all municipal and some state schools are included in the Program regarding oral health actions. This explains the greater capture of sentinel children in municipal schools [28]. The small capture number of the sentinel event in the spontaneous demand of the health center denotes fragility in the insertion of oral health in the work integrated with the FHS. The participation of Oral Health Teams at events such as vaccination campaigns contributes greatly to identify sentinel event children who are out of school and social programs. Vaccination campaigns, moreover, have become strategically important in health diagnosis and 
surveillance actions, since they increase the access of the entire population of a given age group or condition in the life cycle to health services [29]. This strategy is part of the municipal oral health policy of Belo Horizonte.

In low-risk areas it was expected to find fewer children sentinel event. Nevertheless they appeared in the regional centers of South and Pampulha that present a better purchasing power. This probably occurs because there is less investment by the Municipal Health Department of Belo Horizonte in areas of lower vulnerability to health. Further research on this subject should be developed for the improvement of public policies that can prevent such a serious oral health situation.

\section{CONCLUSION}

The study demonstrates that the adoption of comprehensive social policies can influence the oral health situation such as the Bolsa Família Program, Family Health Strategy and $\mathrm{BH}$ Citizenship. It is of utmost importance

\section{REFERENCES}

1. Rutstein DD, Berenberg W, Chalmers TC, Child CG 3rd, Fishman AP, Perrin EB. Measuring the quality of medical care, a clinical method. N Engl J Med. 1976;294:582-8. doi: 10.1056/ nejm197603112941104

2. Penna MLF. Condição marcadora e evento sentinela na avaliação de serviços de saúde. Texto elaborado para a bibliografia básica do Projeto GERUS. In: Projeto GERUS. Desenvolvimento Gerencial de Unidades Básicas de Saúde do Distrito Sanitário Projeto GERUS. Brasília: Fundação Nacional de Saúde; 1995. p. 121-128.

3. Abreu D, César CC, França EB. Relação entre as causas de morte evitáveis por atenção à saúde e a implementação do Sistema Único de Saúde no Brasil. Rev Panam Salud Publica. 2007;21(5):282-291.

4. Hartz ZMA, Champagne F, Leal MC, Contandriopoulos AP. Mortalidade infantil "evitável" em duas cidades do Nordeste do Brasil: indicador de qualidade do sistema local de saúde. Rev Saúde Pública. 1996; 30(4):310-318. doi: 10.1590/S003489101996000400004

5. LanskySM, FrançaE, LealMC. Mortalidadeperinataleevitabilidade: revisão da literatura. Rev Saúde Pública. 2002;36(6):759-772. doi: 10.1590/S0034-89102002000700017

6. Malta DC, Duarte EC. Causas de mortes evitáveis por ações efetivas dos serviços de saúde: uma revisão da literatura. Ciênc Saúde Coletiva. 2007;12(3):765-776. doi: 10.1590/S141381232007000300027.

7. Puccini PT, Cornetta VK. Ocorrências em pronto-socorro: eventos sentinela para o monitoramento da atenção básica de saúde. that in order to solve sentinel events in oral health, several sectors work together in order to plan and evaluate the developing public health policies. However, it is necessary to develop another study with this same design involving children up to six years of age who are not sentinel event, for comparison purposes. A relevant point of this research was the need to organize, systematize, disseminate and analyze existing data. This study points out the importance of developing qualitative research on the subject that can also highlight other important aspects, observed in the daily routine of the research, such as the violence and the abandonment in which these children live.

\section{Collaborators}

NNR PEREIRA, SM PAIVA, RS PINTO and SD LUCAS acted in the conception, design, analysis, interpretation of data and end of the article. EMO SÁ he served in the analysis and interpretation of data.

Cad Saúde Pública. 2008;24(9):2032-2042. doi: 10.1590/ S0102-311X2008000900009

8. Silvino MCS, Rosa NM, Santos JAT, Seleghim MR, Ballani TSL, Oliveira MLF. Operacionalização de evento sentinela para vigilância do uso de drogas de abuso. Saúde \& Transformação Social/Health \& Social Change. 2012;3(2):59-66.

9. Wigglesworth JS. Monitoring perinatal mortality: a pathophysiological approach. Lancet. 1980;2(8196):684-686. doi: 10.1016/S0140-6736(80)92717-8

10. Belo Horizonte. Secretaria Municipal de Saúde. RAG Relatório Anual de Gestão de 2009, de 21 de Fevereiro de 2011 [citado 2016 Nov 12]. Disponível em: <http:// portalpbh.pbh.gov.br/pbh/ecp/noticia.do? evento=portlet $\&$ $\mathrm{pAc}=$ not\&idConteudo=44694\&pldPlc=\&app=salanoticias $>$.

11. Brasil. Ministério da Saúde. Secretaria Executiva/ Departamento de Informática do SUS $₫$ DATASUS / Coordenação Geral de Disseminação de Informação em Saúde - CGDIS. Equipe FormSUS. FormSUS: manual do gestor. Rio de Janeiro: Ministério da Saúde; 2016.

12. Belo Horizonte. Secretaria Municipal de Saúde. Índice de Vulnerabilidade à Saúde, 2012 [citado 2016 Nov 28]. Disponível em: <file:///C:/Documents\%20and\%20Settings/prps001555/ Meus\%20documentos/Downloads/ivsaude-risco2012.pdf>.

13. Belo Horizonte. Secretaria Municipal de Políticas Sociais. Programa BH Cidadania: Programa de Desenvolvimento Integrado [citado 2016 Nov 28]. Disponível em: <http:// portalpbh.pbh.gov.br/pbh/ecp/comunidade.do?evento=portlet \&pldPlc=ecpTaxonomiaMenuPortal\&app=politicassociais $\&$ tax $=8$ 962\&lang=pt_BR\&pg $=5567 \& \operatorname{taxp}=0 \&>$.

14. Piza E, Rosemberg F. Cor nos censos brasileiros. Rev 
USP.1999;40:122-137.

15. Guiotoku SK, Moysés ST, Moysés SJ, França BHS, Bisinelli JC. Iniquidades raciais em saúde bucal no Brasil. Rev Panam Salud Publica. 2012;31(2):135-41.

16. Rodrigues AP, Matias F, Ferreira MM. Escovagem de dentes em ambiente escolar e redução do índice de placa bacteriana: avaliação da efetividade de um projeto de saúde oral. Rev Port Saúde Pública. 2016;34(3):244-249. doi: 10.1016/j. rpsp.2016.06.002

17. Almeida TF, Vianna MIP, Cabral MBBS, Cangussu MCT, Floriano FR. Contexto familiar e a incidência de cárie dentária em crianças pré-escolares que vivem em áreas cobertas pela Estratégia de Saúde da Família em Salvador, Bahia, Brasil. Cad Saúde Pública. 2012;28(6):1183-1195. doi: 10.1590/S0102$311 \times 2012000600017$

18. Bonanato K, Scarpelli AC, Goursand D, Mota JPT, Paiva SM, Pordeus IA. Senso de coerência e experiência de cárie dentária em pré-escolares de Belo Horizonte. Rev Odonto Cienc. 2008;23(3):251-255.

19. Peres MA, Latorre MRDO, Sheiham A, Peres KG, Barros FC, Hernandez PG, et al. Determinantes sociais e biológicos da cárie dentária em crianças de 6 anos de idade: um estudo transversal aninhado numa coorte de nascidos vivos no Sul do Brasil. Rev Bras Epidemiol. 2003;6(4):293-306. doi: 10.1590/S1415790X2003000400004

20. Tomita NE, Bijella VT, Lopes ES, Franco LJ. Prevalência de cárie dentária em crianças da faixa etária de 0 a 6 anos matriculadas em creches: importância de fatores socioeconômicos. Rev Saúde Pública. 1996;30(5):413-420. doi: 10.1590/S003489101996000500003.

21. Cypriano S, Sousa MLR, Rihs LB, Wada RS. Saúde bucal dos pré-escolares. Rev Saúde Pública. 1999;37(2):247-253. doi: 10.1590/S0034-89102003000200014.

22. Antunes JLF, Peres MA, Mello TRC. Determinantes individuais e contextuais da necessidade de tratamento odontológico na dentição decídua no Brasil. Ciênc Saúde Coletiva. 2006;11(1):7987. doi: 10.1590/S1413-81232006000100015
23. Mello TRC, Antunes JLF, Waldman EA. Prevalência de cárie não tratada na dentição decídua em áreas urbanas e rurais do Estado de São Paulo, Brasil. Rev Panam Salud Publica. 2008;23(2):7884. doi: 10.1590/S1020-49892008000200002

24. Brasil. Ministério do Desenvolvimento Social e Agrário, Programa Bolsa Família. 2004 [citado 2016 Set 19]. Disponível em: <http:// mds.gov.br/assuntos/bolsa-familia/o-que-e>.

25. Belo Horizonte. Secretaria Municipal de Saúde. Protocolo para atenção básica em saúde bucal - junho/2006 [citado 2016 Dez 12]. Disponível em: <http://portalpbh.pbh.gov.br/pbh/ecp/ comunidade.do?evento=portlet\&pldPlc=ecpTaxonomiaMenuPo rtal\&app=saude\&lang=pt_BR\&pg=5571\&tax=25601 > .

26. Minas Gerais. Secretaria Estadual de Educação. Educacenso. 2015 [citado 2016 Nov 28]. Disponível em: <https://www.educacao.mg.gov.br/images/documentos/ Educa\%C3\%A7\% C3\%A30\%20em\%20Minas\%20Gerais\%20 -\%20Educacenso\%202015.pdf>.

27. Frias AC, Antunes JLF, Junqueira SR, Narvai PC. Determinantes individuais e contextuais da prevalência de cárie dentária não tratada no Brasil. Rev Panam Salud Publica. 2007;22(4):279285.

28. Brasil. Ministério da Saúde. Secretaria de Atenção à Saúde. Departamento de Atenção Básica. Instrutivo Programa Saúde na Escola/Ministério da Saúde. Secretaria de Atenção à Saúde. [citado 2016 Dez 12]. Disponível em: <http://189.28.128.100/ dab/docs/legislacao/passo_a_passo_pse.pdf>.

29. Belo Horizonte, Secretaria Municipal de Saúde. Relatório Anual de gestão 2012 [citado 2016 Dez 11]. Disponível em: <http:// portalpbh.pbh.gov.br/pbh/ecp/comunidade.do?evento=portlet \&pldPlc=ecpTaxonomiaMenuPortal\&app=saude \&tax=15436\&la ng=pt_BR\&pg $=5571 \& \operatorname{taxp}=0 \&>$.
Received on: 27/5/2017

Final version resubmitted on: 11/9/2017

Approved on: 2/10/2017 